\title{
A historical Jesus hallucinating during his initial spirit-possession experience: A response to Stevan Davies' interpretation of Jesus' baptism by John
}

\author{
Johan Strijdom \\ Temporary part time lecturer: \\ Department of New Testament Studies (Sec A) \\ University of Pretoria
}

Tell us the content of your vision. And then we will have to judge, not whether you had it or not, but whether we should follow it or not.

(Crossan 1998:xviii)

\begin{abstract}
Taking Albert Schweitzer's threefold criticism of psychological readings of the historical Jesus as point of departure, Davies' analysis of Jesus' baptism is critically assessed in terms of (1) his database of sources, (2) his arguments for authenticity, and (3) his psychological explanation of this crucial event in Jesus" life. The article insists, in conclusion, that Davies' psychological analysis should be supplemented with a consideration of social values if we wish to understand the nistorical Jesus better.
\end{abstract}

\section{INTRODUCTION}

In his 1913 medical dissertation, translated later as The psychiatric study of Jesus, Albert Schweitzer set out to critically assess three then recent treatises in which it was argued that Jesus had been mentally diseased. Jesus was labelled by those early twentieth-century writings as mad/insane/deranged/psychotic. It was claimed that Jesus was a psychopath of the paranoid type, a sick man with a serious mental disorder who had lost touch with reality and had experienced apocalyptic delusions of a religious nature and hallucinations of persecution and megalomania ${ }^{1}$. Schweitzer's criticism of those studies centered around three basic points:

* This article was submitted as part of the requirements for the DD-degree (1998) in the Faculty of Theology (Sec A), University of Pretoria, with Prof Dr A G van Aarde as supervisor. The article is based on parts of chapter 2 of the dissertation: 'An evaluation of John Dominic Crossan's construct of the historical Jesus: The Baptist as test case'. Dr Strijdom is Senior Lecturer in the Department of Classics at the University of South Africa. 


\subsection{The need for a historical-critical analysis of primary sources}

Firstly, Schweitzer (1950:45) accused his learned colleagues of being 'completely uncritical not only in the choice but also in the use of sources' and therefore first sketched what he considered to be 'the results achieved by the criticism of sources and by the scientific study of the life of Jesus.' His portrait of Jesus, as is well known, was based on Matthew (first two chapters excluded) and Mark, and presented a Jesus whose apocalyptic message had proved to be thoroughly mistaken. Schweitzer (1950:49) summarized the content of Jesus' initial message in Mark 8:34-9:1 as follows:

He proclaims the nearness of the Kingdom and of the judgment. At the same time he amplifies his message by explaining in what the repentance and morality which are necessary for justification at the jugment consist, and reminds them of the great misery which still stands before them. He who is faithless in the time of persecution is lost; he who wishes to save his earthly life will lose his' eternal life. Concerning himself Jesus expects that he must at that time endure great disgrace and persecution and implores his followers not to be led astray then, and in spite of all, to remain loyal to him.

\subsection{Jesus' social-historical context with its peculiar belief-systems}

Secondly, Schweitzer (1950:72) charged the authors under discussion of being 'too little acquainted with the contemporary thought of the [i e, Jesus' - JS] time to be able to do justice to it.' He argued that Jesus' apocalyptic message would have been clearly understood by his original audience, since they would have been familiar with that mentality from literature like Encch and Daniel. Schweitzer (1950:60-61) gave the following summary of what he perceived to be the commonly accepted ideas of Jesus' society:

The view that the present world has been given over to the evil spirits, who can even take possession of men and speak through them; the expectation that the good angels led by the Messiah will take over the rule of the world; the belief in the coming of the Messianic Kingdom with all the subsidiary ideas - the misery that is to precede the Messiah, the judgment, the annihilation of the wicked, the resurrection and 'transformation' of the just and the elect, the transfiguration of earthly nature into a state of supernatural fertility - which appears in the prophetic books and in the apocalypses. 


\subsection{The validity of labelling Jesus as mad}

Schweitzer's central challenge, however, clearly lay in the fact that he contested the validity of labelling Jesus as insane. His argument: those labels are not applicable to the historical Jesus, since, within the context of his world, Jesus' beliefs and practices would have been considered quite normal and acceptable. It is, in Schweitzer's opinion, psychiatrically unsound to treat Jesus' ideas and practices out of their original social-historical context and predicate them with prejudiced notions of the twentieth century. He furthermore held that, even by twentieth century standards, Jesus could not be labelled as paranoiac (the opposition he had faced, had been real and no mere delusion) and his hallucination at his baptism should not necessarily be interpreted as abnormal (even in a modern context not every hallucination should be considered aberrant).

Schweitzer's (1950:72) conclusion was that, in studying the historical Jesus, there are two 'symptoms to be accepted as historical and possibly to be discussed from the psychiatric point of view - the high estimate which Jesus [had] of himself and perhaps also the hallucination at the baptism'; Schweitzer simultaneously, however, insisted emphatically that those symptoms 'fall far short of proving the existence of mental illness.'

It will be my purpose in this article to critically assess Davies' (1995:8) 'comprehensive thesis' on the historical Jesus, by focusing on his interpretation of Jesus' baptism. Davies (1995:51) is, it should be remembered, adamant that the baptism presents 'the right point' to begin any study of the historical Jesus' 'career' (Davies 1995:54). He holds firmly that Jesus' baptism forms 'the foundational event of his life' (Davies 1995:51), since it was on that occasion that Jesus had his 'initial spirit possession experience' (Davies 1995:59) - an intense dissociative experience which influenced his further ministry decisively and determined his 'new social role' (Davies 1995:65) as spirit-possessed healer definitively. My appraisal of Davies' important contribution will be guided by two leading questions:

\subsection{Which sources?}

Which sources on Jesus' baptism are to be considered and how can we analyse them to arrive at judgments on historical probability?

What is the upshot of Davies' psychoanalytic interpretation of Jesus' baptism and how can this approach be developed further by considering the social function(s) that Jesus' baptism served? It will become clear from my discussion that the issues raised by Schweitzer more than eighty years ago are still pertinent, but that the material investment made in the meantime has been considerable. It will be my objective not only 
to highlight points of major progress in Davies' study, but also to identify certain shortcomings in his work and propose possible avenues to explore further if we wish to progress beyond the identified problems.

\section{PRIMARY SOURCES AND CRITERIA FOR DETERMINING AUTHENTI- CITY: JESUS' BAPTISM BY JOHN AS TEST CASE}

\subsection{Primary sources}

For his construct of John's preaching and Jesus' baptism by John, Davies is dependent on the canonical gospels, $Q$ and Acts. This is in marked contrast with the Jesus Seminar (Tatum 1994) and Crossan's (1991) plea to discipline canonical bias and include all early Christian literature prior to $150 \mathrm{CE}$ in the database for critical analysis. It is unclear whether Davies shares Meier's (1991) skepticism about the historical worth of extra-canonical writings, or whether he would accept Koester (1990) and Crossan's (1985) historical arguments on canon formation which would necessitate the inclusion of these documents in an initial database. Crossan (1991), for example, includes in his Baptist index not only Thomas (which is indeed considered by Davies elsewhere), but also the Gospel of the Hebrews, Apocryphon of James, Gospel of the Nazoreans, Gospel of the Ebionites and Ignatius' letters to the Ephesians and Smymeans. The important evidence from Josephus' Antiquities receives, of course, its due recognition in Crossan's analysis as well. The first point of criticism, then, exposes the lack of clarity on sources in Davies' database and pleads for an explicit statement in this regard (as we find in Crossan and the Jesus Seminar's work).

\subsection{Analysis of sources and criteria of authenticity}

Davies (1995:55-56) holds that 'the events given and implied in Mark's account, including various "supernatural" events, happened pretty much as Mark says they happened.' This statement may lead one to suspect a historically naive procedure on Davies' part. This is however not the case, since Davies does substantiate his arguments for historical elements in the Markan narrative by invoking the standard criteria of embarrassment, multiple attestation, dissimilarity, and coherence. These criteria are employed in the following ways to argue for the authenticity of the indicated elements:

\subsubsection{The criterion of embarrassment}

Davies finds this criterion the most persuasive in arguing for the historicity of Jesus' baptism by John. According to this criterion all four evangelists were embarrassed by 
what happened originally ('a repentant Jesus humbling himself before John') and therefore modified the original fact to portray instead a sinless and superior Jesus versus an inferior John who 'recognized Jesus as his superior' (Davies 1995: 52). It was especially Matthew, Luke and John who 'understood the derogatory implications of the Baptism story and worked to explain them away' (Davies 1995:53). This apologetic tendency is, of course, clearest in Gospel of the Nazoreans 2, which is not mentioned by Davies. Here Jesus himself explicitly asserts his sinlessness and denies his need to be baptized by John.

This criterion is also invoked by Davies (1995:61) to claim authenticity for Jesus' vision of an open heaven and the spirit descending like a dove. John 1:32, probably out of embarrassment, attributed the vision of the dove to the Baptist instead of Jesus.

\subsubsection{The criterion of multiple attestation}

Since the baptism story is found in five sources ('Matthew, Mark, Luke, and by implication, John and Q' [Davies 1995:53]), and three of these ('Q, Mark, John' [Davies: 55]) are judged to be independent, the story can be presumed to contain a historical kernel. The assumption here is that 'the more numerous the independent sources that contain an account of a deed or saying of Jesus the more likely it is to be an authentic account' (Davies 1995:53, note 2).

Davies specifically argues that it is unlikely that Mark 1:11 invented Jesus' hearing a voice from heaven telling him he (= the spirit) was God's Son, since John 1:33-34 as independent source ' $k$ new of an association between the descent of the spirit upon Jesus and immediate witness that he was Son of God' (Davies 1995:61). In Davies' (1995: 61) view 'Jesus did regard himself as the Son of God.'

\subsubsection{The criterion of dissimilarity}

According to this criterion 'words or deeds of Jesus that cannot be derived either from Judaism at the time of Jesus or from the early Church' (Davies 1995:53, note 2) have a claim to authenticity. Davies (1995:53) holds that the baptism story contains historical truth since 'nowhere else in Judaism or early Christianity is it attested that the Holy Spirit descends during a Johannine baptism (Luke specifically denies this in Acts 19:16), or during any.other Jewish immersion ritual.' He furthermore finds no evidence in the Jewish tradition of 'the spirit of the Jewish God appearing in the form of a dove' (Davies 1995:61) and therefore concludes that rather than presume this story was made up by someone, he accepts it as historical: it is 'most likely' that 'Jesus saw the spirit descend in the form of the dove' and told his followers about it. 
Davies (1995:61) also argues on the basis of this criterion that Jesus most probably did hear a voice from heaven telling him that he (= the spirit) was God's Son. He thinks it is a certain fact that Jesus equated spirit with Son, since this equation was unprecedented in contemporary Judaism. 'Jesus identified the spirit by which he was possessed as the son because ... Jesus heard something to the effect "this [the spirit] is my beloved Son"' (Davies 1995:62).

\subsubsection{The criterion of coherence}

This criterion depends to a certain extend on 'circular reasoning' (Davies 1995:53). It presumes that 'if a saying or deed is coherent with an established set of authentic sayings or deeds it is also likely to be authentic.' On account of the nature of this kind of argument, it is only mentioned here in anticipation of fuller argumentation later in his work.

From this survey it is clear that Davies has argued, on the basis of canonical sources and the standard criteria of authenticity, for the following facts in the life of the historical Jesus:

* Jesus was baptized by John. He was clearly inferior to John, became aware of his sins under John's preaching, repented and had himself baptized by John.

* At his baptism Jesus saw the heavens opened and the spirit descend on him like a dove. He also heard a voice, saying something to the effect of, "This (= the spirit) is my beloved Son.'

Davies' arguments in connection with John's preaching are, however, less clear. He correctly observes that the Baptist was thought of as a prophet on the basis of independent attestation in Q 7:24-28 and Mk 11:32. But for the supposed threats in John's preaching he offers only the singular evidence from $Q$ 3:7-9, 16-17 and the general statement that 'a preacher of repentance will normally combine threat and promise' (Davies 1995:56). Is it possible to adduce any other evidence or invoke any specific criterion to substantiate the historicity of John's threats of apocalyptic judgment? The second point of criticism, then, asks for clarification of arguments on the proposed historicity of elements in John's preaching. How do we know that John included apocalyptic threats in his proclamation?

It is at least clear to me that the authenticity of the following elements in John's preaching and practice can be argued convincingly on the basis of independent attestation: 
* John expected someone stronger and other than himself to intervene, someone who would baptize with the Holy Spirit. This aspect of John's preaching is attested independently in Mark 1:7-8 and Q 7:16. Davies (1995:60), however, although he considers it possible, is uncertain whether 'John predicted the arrival of One to Come who would baptize with spirit.' He does not refer to the independent sources, but simply gives Scobie's arguments for the authenticity of the Baptist's 'prediction of a future "outpouring" of God's spirit.' The reasons: it is 'in accord with John's other eschatological teachings and ... also ... with some Jewish thought of the time' (Davies 1995:60). He then quotes Scobie's conclusion that John spoke not only 'of God's "holy spirit"' but also 'of a Messiah who would baptize, not with water as John himself did, but with both fire and holy spirit' (Davies 1995: 60 ). The reasoning here should clearly proceed more carefully: Of the spirit baptism we have independent attestation, but of the fiery aspect not. Furthermore, the use of the term 'Messiah' for the agent of the action is problematic and in need of clarification.

* John exhorted people to repent, that is to change their hearts and their ways (which meant removal of their sins by God), before they could undergo his baptism. How do we argue for the authenticity of these elements in the Baptist's preaching? It is possible to read the Baptist's call for a mental change and the practicing of $\dot{\alpha} \rho e r \dot{\eta}$ in Ant 18:117 as semantically comparable with the Baptist's exhortation to

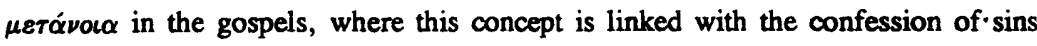
(Mk 1:5) and good works (Q 3:8). If the correlates are as follows, we have inde-

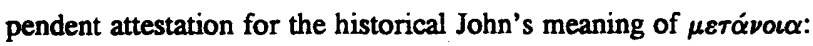

** As to the Baptist's call for a change of heart: In Mark 1:5 John's baptism is

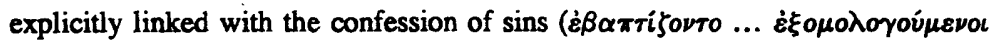
$\tau \dot{\alpha} \varsigma \dot{\alpha} \mu \alpha \rho \tau i \alpha \varsigma$ ) and in Josephus the purification of the soul ( $\tau \hat{\eta} \varsigma \psi \psi v x \hat{\eta} \varsigma$

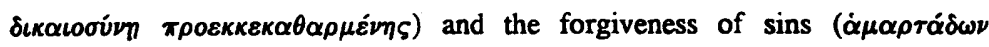
$\left.\pi \alpha \rho \alpha \iota \tau^{\prime} \sigma \varepsilon l\right)$ are explicitly supposed to precede John's baptism.

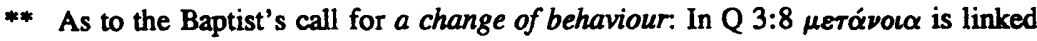
with good works ( $\alpha \alpha \rho \pi \circ \grave{\varsigma} \dot{\alpha} \xi i$ iov $\mu \varepsilon r \alpha \nu o i \alpha \varsigma$ ), which is parallelled by Josephus' practicing of $\dot{\alpha} \rho \varepsilon r \dot{\eta}$. 
My proposal, then, is that arguments like these are imperative to claim historicity for elements in John's preaching rather than merely assume their authenticity at face value.

\subsection{Davies' historical facts in connection with John's preaching and Jesus' bap- tism}

For the sake of clarity and as base for subsequent reasoning, Davies' historical facts concerning John's preaching and Jesus' baptism can be summarized as follows:

* John was a 'spirit inspired' (Davies 1995:60) prophet who preached apocalyptic threats and promises to his audience, in the light of which they were called upon to repent of their sins and receive his baptism. What he did was to 'convince (his) hearers that they were sinful' (Davies 1995:64), to insist on the necessity of their repenting of their sins ( $\mathrm{i}$, to undergo a 'psychological change') and to practice 'works to cause such a change' (Davies 1995:56), which meant forgiveness of their sins.

* John probably 'predicted the arrival of One to Come who would baptize with spirit,' 'of a Messiah who would baptize, not with water as John himself did, but with both fire and holy spirit' (Davies 1995:60).

* Jesus of Nazareth, along with numerous other people, went to the Jordan river circa $28 \mathrm{C} \mathrm{E}$.

* Those who went to John came to regard themselves as sinners, repented of their sins and were baptized/immersed by him. They were clearly subordinate to the Baptizer.

* This general statement also applies to Jesus. Like the others Jesus also came to regard himself as a sinner, repented of his sins and was baptized/immersed by John.

* At this occasion Jesus saw a vision ("he saw the heavens opened and the spirit descend upon him like a dove') and heard a voice from heaven (which said to him something like, 'You are my beloved son; with you I am well pleased'). 
* It is a historically certain fact that 'Jesus experienced reception of the spirit at his baptism' (Davies 1995:53). If John did indeed predict the arrival of God's spirit in the future, Jesus could probably have interpreted his spirit experience at his baptism as the realization of John's prediction.

So far I have shown:

* that Davies' initial database of primary sources is too limited, and

* that his arguments on historical elements in the Baptist's preaching are unsatisfactory and in need of elucidation.

I will now turn to a consideration of his psychological interpretation of these proposed historical facts and indicate how social considerations need also be taken into account to understand the full import of Jesus' baptism.

\section{PSYCHOLOGICAL AND SOCIAL INTERPRETATIONS OF JESUS' BAP- TISM}

Davies' major contribution lies in the way he applies the insights of modern, rational psychology to ancient phenomena and events, in the present case specifically John's preaching and Jesus' baptismal experience. He emphatically holds that the story of Jesus' baptism (according to the basically reliable Markan version) is not in the first place about John but about Jesus. It is fundamentally a story of Jesus' spirit-possession, which was caused/facilitated by John's apocalyptic preaching and baptismal ritual. The event is rationally understandable from a modern psychological perspective: under 'those psychologically facilitating circumstances (John's baptism)' (Davies 1995:64), Jesus entered for the first time in his life 'into a state of alter-persona consciousness, which he came to define as possession by God's spirit' (Davies 1995:65). At that occasion and because of it, he experienced his first 'dissociative psychological transformation' which gave him a new status which resulted in his 'new social role' as 'a spiritpossessed man'. 'What Jesus of Nazareth formerly could not do, the spirit of God subsequently could do' (Davies 1995:65).

Since this rational explanation of Davies is so important (it concerns the heart of his contribution), I shall summarize its main points before I introduce my plea that Davies' psychological interpretation must be supplemented with a consideration of the social meaning of Jesus' baptism. 
3.1 Summary of Davies' psychological interpretation of Jesus' baptismal experience as caused by the Baptist's preaching and ritual

The first point to emphasize in a psychological understanding of Jesus' baptismal experience is the fact that John was clearly seen as an authoritative/normative model by Jesus (at least at his baptism). Jesus not only believed what this prophet was preaching, but also saw in him 'the potentiality of humans to be inspired by the spirit of God' (Davies 1995:65). This is comparable to the position of power that modern revival preachers hold over their audiences. It is in such circumstances (when the authoritative and selfconfident preacher serves as model of spirit-inspiration/spirit-possession and attests to 'the benefits of the state') that individuals 'are ... prone spontaneously to achieve the state' (Davies 1995:58).

The second point to grasp is that the kind of rhetoric one finds in John's preaching is exactly the type one can expect to cause a spontaneous possession experience. Like revival preachers in our own day, John 'combine(d) threat and promise' (Davies 1995: 56) in order to 'adduce repentance among sinners' (Davies 1995:57). The repentance

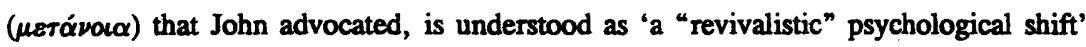
(Davies 1995:59) from regarding oneself as a sinner to accepting oneself as forgiven. What John actually did, was to convince his audience first that they were despicable sinners who would be judged fiercely if they stayed in that condition, and then to offer them a promising 'way out, possession by the Holy Spirit and accordingly, forgiveness of sins' (Davies 1995:57). John's insistence that his audience had first to denigrate their existing self-concepts ( $=$ come to regard themselves as sinners) before they could be forgiven, created the ideal condition conducive to a dissociative experience. It is possible to understand the psychological dynamics of Jesus' first spirit-possession experience in precisely these terms and against this background: it can be assumed that Jesus came to regard himself as a sinner, 'as a viper, a barren tree, as chaff and so deserving of destruction' (Davies 1995:56-57), and that this 'sense of worthlessness' set on and was replaced by an euphoric altered state of consciousness.

The final, and most important, issue to underline concerns the way Davies interprets Jesus' initial possession experience itself ( $=$ his 'reception of the spirit'). During his baptismal experience Jesus saw a vision and heard a voice, which - from a modern, rational psychological perspective - can be understood as a spontaneous visual and auditory hallucination. A hallucination is defined as a mental image/voice that originates from a subject's unconscious mind but is attributed to an external, authoritative source (e $g$, God, a demon, or an ancestral spirit) by the hallucinator himself/herself. ${ }^{2}$ Such hallucinatory experiences are not uncommon during ecstatic trances of psychological dissociation, in which ego boundaries are lost and the subject experiences what 


\section{A historical Jesus hallucinating}

seems to him/her the presence of an alternative, authoritative (divine) personality in his/her body, who is believed to communicate valid and certain truths. What happened in Jesus' case was that, when he entered a state of possession trance at his baptism, he experienced 'a change in personal identity so that he ... (felt) himself ... to be, and (was) socially defined to be, some other person altogether' (Davies 1995:26). He came to identify this alter-persona as the benevolent spirit of God, who was useful to his society, rather than as a malevolent demon who was destructive to his society (Davies 1995:31). This 'type of human experience' is interpreted psychologically as 'the activation of an alternative persona from the existing psychological potential of a particular human being' (Davies 1995:29); it is actually the hearing/seeing of the subject's own unconscious voice/mind. As such the alter-persona can be understood as a constructive way to 'go around the normal ego's defense mechanisms and tap into the unconscious,' as a mechanism to gain 'access to otherwise unavailable unconscious potentials' (Davies1995:40-41) which are normally repressed/inhibited by the primary ego.

The important point to note is that spirit-possession in Jesus' social context meant power. Jesus' dissociative experience gave him an elevated status among his sympathizers, but that new authoritative role simultaneously and inevitably introduced the possibility of power conflicts with opponents. Not everybody would interpret his possessed state as attributable to the spirit of God. As Davies (Davies 1995:31) appropriately observes: "The question of whether a person's possession status is to be labeled "demon" or "spirit" iepends on the perspective of the observer.' He believes that 'in cases of this sort the debate is not in regard to an individual's experience of possession but in regard to whether that possession is or is not beneficial or acceptable to society' (Davies 1995:31). With this statement we arrive at my final section: a plea for a serious consideration of the social significance of Jesus' baptismal experience.

\subsection{Jesus joined a baptist/millennialist movement: The social significance of Jesus' baptism by John}

Josephus (Ant 18.117-118) informs us that more and more people were joining John's

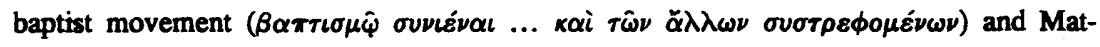
thew 14:5 also mentions the formation of a crowd (ox $\left.{ }^{\circ} \circ \varsigma\right)$ around John. We can thus, on the basis of independent attestation, accept it as a historical fact that, when Jesus went to be baptized by John, he joined a movement. Two things are clear about this social formation from previous studies (for references, see Strijdom 1998), which can now be supplemented with Davies' emphatic point on spirit-possession: 
* Firstly, the sect practiced a water ritual, which when compared with contemporary Palestinian purificatory practices, showed certain unique characteristics. As opposed to Qumran's self-administered and ceaseless ablutions in ritual baths, John's baptism/immersion was administered to new members by himself in the Jordan river and probably only once as an unrepeatable initiation rite. In both cases, however, true 'inner repentance and obedient lives' were considered to be prerequisites for undergoing the water rituals (Meier 1994:50). It is clear that the Essenes was highly critical of the Temple elite at that time and it is probable, though not sure, that John's ritual was practiced in deliberate opposition to the Temple cult which served, primarily by means of sacrifices, as the official mediator of divine forgiveness.

* Secondly, John's sect was a millennialist movement which should be understood in comparison and contrast with other apocalyptic groups from John's time and in the vicinity of his appearance. It is especially the correspondence with lower-class millennialist movements from Josephus that has featured prominently in this comparative analysis. Crossan $(1991,1994)$, for example, interprets these movements as non-violent forms of resistance to exploitation by the Temple elite and Roman/ Herodian rulers. What these prophets were doing, was to promise imminent divine liberation for the oppressed and to symbolically enact their message by 'reenacting, as it were, the ancient model of Moses and Joshua leading the Israelites out of the desert and into the Promised Land' (Crossan 1994:41).

In my doctoral thesis (Strijdom 1998), I have challenged Crossan's proposal by arguing that the Baptist with his apocalyptic message and water ritual was closer to dissident 'retainers' behind the Qumran writings, Psalms of Solomon, Testament of Moses and Similitudes of I Enoch than the lower-class 'sign-prophets' of Josephus: not only did he expect God to intervene through an agent to set wrongs right, but he also insisted that people in his audience should begin to live $a$ pure/moral life in accordance with the Torah before they could undergo his baptism as a sign of their repentance. His criticism of Antipas' impure marriage would have received a positive response from illiterate peasants and like-minded dissident 'retainers' in his audience, as well as from the neigbouring Nabateans who were offended by Antipas' rejection of their own princess.

* Davies has made us aware of a third aspect, which needs to be applied to John's sectarian movement. In his general discussion of possession phenomena, Davies (1995:35-36; my emphasis) correctly observes: 
The practice of spirit-possession is essentially social in nature. Rarely do individuals enter a possession state in solitude for their own personal benefit. People who become possessed do so in the presence of others and communicate with others. As E M Pattison writes, possession trance is 'an interpersonal event, in which there is possession by, or entranced impersonation of, another being, in the context of communal activity and witness to the behavior.' Possession is a communication medium that in theory allows human beings to communicate with gods, but which in fact allows a transformed manner of communication between human beings and other human beings.

It is, however, unfortunate to my mind that when Davies discusses Jesus' initial spirit-possession and hallucination at his baptism (Chapter 4 of his book), he rarely refers back or applies his general remarks on the social function of spirit-possession (see Davies 1995:35-36), but rather prefers to emphasize now instead that 'evidence reporting metanoia, repentance, and visionary and auditory experience on the order of hallucination ... is, first and foremost, evidence concerned with psychological states and events' (Davies 1995:59-60; my emphasis). What he does underline in Chapter 4 is that 'the psychological conditions that engender spirit-possession were in effect for Jesus and the cultural conditions that permit spirit-possession were also in effect' (Davies 1995:59). What I would have liked to see in addition, however, is an explication of the communal function of Jesus' experience. My third and final criticism of Davies is then actually a request that he applies some of his own general remarks on the social functions of spirit-possession to Jesus' initial spirit-experience itself.

To make my plea clear, I will quote some of Davies' general observations and show how they may be applied to the posed problem. The crucial insight that goes to the heart of the matter concerns the social value systems that determined whether Jesus' spirit was defined as benevolent or malevolent. The label depended 'on the perspective of the observer' (Davies 1995:31). Davies himself introduces the notion of social classes with conflicting value systems, which provides in my opinion the key to answering our question. On the one hand there are 'the elite in a given society' with their own 'value systems'; on the other hand there are those who 'challenge elite values'. He also notes later that 'people of relatively low social status, marginal people, people in a condition of social oppression' tend to 'join possession-oriented groups' (Davies 1995: 39). The question then is: To which social group did the historical Jesus belong and which value system did his initial spirit-possession and hallucinatory experience serve?

I have already referred to Crossan's thesis on John's movement as an example of peasant millennialism, and my own thesis of John as a dissident 'retainer' with a fol- 
lowing amongst peasants and other dissident 'retainers'. If we locate Jesus amongst the lower-classes and interpret his career as intended to build the oppressed rural society in the Galilee of his day from its grassroots level upward, his life bears witness to a criticism 'from below' of the religious and political perpetrators of social injustice. His temple critique is clear from the end of his life (cf Crossan 1991:355-360); it may well be that his acceptance of John's ritual at the beginning of his career already served as opposition to the official mediators of forgiveness (cf my argument above). Furthermore, it can be accepted as historical facts that John was critical of Antipas' immoral life (it probably caused his death) and that Jesus scathingly remarked about Antipas' lascivious lifestyle (John's execution by Antipas is recorded independently in Ant 18.117a and Mk 6:27, although a political reason is given in the first and a moral one in the second source; the latter fact is attested independently in Thom 78 and Q 7:24 25). It is clear that, within this context, Jesus' initial spirit-possession would have given him a position of power which was considered beneficial by his in-group, but considered malevolent by the elites who were criticized by him.

What is unclear to me is why Davies seems so hesitant to ponder these social consequences of his own argument. Is it only a question of being 'suspicious' of a picture of Jesus 'who is just like one of us, one who holds values that are very close to our ideological commitments, a Jesus who is a social reformer ..., who can stand as an example and inspiration for worthy causes' (Davies 1995:9)? Davies, in his discussion of a hallucinating and spirit-possessed Jesus, is careful to indicate that Jesus should not be considered mad/psychotic: 'Possession is not, per se, a pathological disorder, since individuals who experience possession do so ... for their own benefit and for the benefit of their local social groups' (Davies 1995:38). Elsewhere we hear that 'an alternative ego structure can, as it were, go around the normal ego's defense mechanisms and tap into the unconscious' so that individuals can thus 'attain knowledge and insight into personal and social circumstances that they cannot attain in a normal persona state' but which 'may be surprisingly apt' and 'will often have real value' (Davies 1995:41). It seems to me that the real problem may lie with an idealization of the trance state per se, without taking the inextricably linked relative social value systems seriously: Hitler also heard voices and thus 'tapped into his unconsciousness'. (cf Johnson 1979:8-9). And if we take dream analysis as another way to access our 'unconscious potential' ( $\mathrm{i}$ $e$, in Freudian terms, as an indication of our repressed wishes and fears), Michel Foucault (1984:9) has made us aware of the fact that dreams may be but an indication of 'current modes of valuation and generally accepted attitudes.' The question of social ethics, I maintain in conclusion, is extremely important in our interpretation and evaluation of Jesus' first experience of psychological dissociation. The answer to the question whether it was good or bad to that society, will depend on the class perspective of 
that time from which one imagines the phenomenon. What it really comes to in the end, then, is two questions: firstly, what is the content of the vision, and, secondly, should it be followed (cf Crossan 1998:xviii)?

\section{End Notes}

1 Megalomania can be defined as 'a form of madness in which a person has an exaggerated view of his own importance, power, etc' (Oxford Adwanced Learner's Dictionary).

2 The phenomenon is comparable with ecstatic prophetic speech (which was common in the Greco-Roman and Jewish world of Jesus' time). From a psychological explanatory paradigm the prophetic words do not 'originate externally to the mind of the person uttering them,' but from 'an alter-persona [the persona "spirit of God"] of the original person' which is nothing but 'a feature of the mind' itself (Davies 1995:46).

\section{Works consulted}

Crossan, J D 1985. Four other gospels: Shadows on the contours of canon. Minneapolis: Winston Press.

1993. The historical Jesus: The life of a Mediterranean Jewish peasant. Edinburgh: T \& T Clark.

1994. Jesus: A revolutionary biography. San Francisco: HarperSanFrancisco.

1998. The birth of Christianity: Discovering what happened in the years immediately after the execution of Jesus. San Francisco: HarperSanFrancisco.

Davies, S 1995. Jesus the healer: Possession, trance, and the origins of Christianity. London: SCM.

Foucault, M 1984. The care of the self. The history of sexuality, 3. London: Penguin.

Johnson, F H 1978. The anatomy of hallucinations. Chicago: Nelson-Hall.

Koester, H 1990. Ancient Christian gospels: Their history and development. London: SCM.

Meier, J P 1991. A marginal Jew: Rethinking the historical Jesus, 1: The roots of the problem and the person. New York: Doubleday.

Meier, J P 1994. A marginal Jew: Rethinking the historical Jesus, 2: Mentor, message, and miracles. New York: Doubleday.

Schweitzer, A 1950. The psychiatric study of Jesus: Exposition and criticism. San Francisco: Beacon Press.

Strijdom, J M 1998. An evaluation of John Dominic Crossan's construct of the historical Jesus: The Baptist as test case. DD-thesis, University of Pretoria.

Tatum, W B 1994. John the Baptist and Jesus: A report of the Jesus Seminar. Sonoma, CA: Polebridge. 